\title{
Dietary Sesame Lignans Decrease Lipid Peroxidation in Rats Fed Docosahexaenoic Acid
}

\author{
Saiko IKEDA*, Mieko Kagaya, Katsura KobaYASHI, Tomoko ToHYamA**, Yoshinobu KISO ${ }^{1}$, \\ Naoki HiguCHI ${ }^{1}$ and Kanae YAMASHITA*** \\ Department of Food and Nutrition, Sugiyama Jogakuen University, Nagoya 464-8662, Japan \\ ${ }^{1}$ Institute for Fundamental Research, Suntory Ltd., Osaka 618-8503, Japan
}

(Received March 5, 2003)

\begin{abstract}
Summary We have previously reported that dietary sesamin and sesaminol, major lignans of sesame seed, elevate the $\alpha$-tocopherol concentration and decrease the thiobarbituric acid reactive substance (TBARS) concentration in the plasma and liver of rats. In this study, the effects of dietary sesamin and sesaminol on the lipid peroxidation in the plasma and tissues of rats fed docosahexaenoic acid (DHA, 22:6 n-3) were examined. Male Wistar rats (4wk-old) were divided into the following six experimental groups: control group, fed a basal diet; sesamin group, fed a diet with sesamin $(2 \mathrm{~g} / \mathrm{kg})$; sesaminol group, fed a diet with sesaminol ( $2 \mathrm{~g} / \mathrm{kg}$ ); DHA group, fed a diet containing DHA ( $5 \mathrm{~g} / \mathrm{kg}$ ); DHA + sesamin group, fed a diet containing DHA with sesamin; and DHA + sesaminol group, fed a diet containing DHA with sesaminol. Each diet contained either 0.01 or $0.05 \mathrm{~g} \mathrm{D}-\alpha$-tocopherol $/ \mathrm{kg}$, and the rats were fed the respective experimental diet for $5 \mathrm{wk}$. The dietary DHA elevated the TBARS concentration and also increased the red blood-cell hemolysis induced by the dialuric acid. The dietary sesamin and sesaminol lowered the TBARS concentrations and decreased the red blood hemolysis. The dietary sesamin and sesaminol elevated the $\alpha$-tocopherol concentrations in the plasma, liver, and brain of the rats fed a diet with or without DHA. These results suggest that dietary sesame lignans decrease lipid peroxidation as a result of elevating the $\alpha$-tocopherol concentration in rats fed DHA.
\end{abstract}

Key Words docosahexaenoic acid, lipid peroxidation, sesamin, sesaminol, $\alpha$-tocopherol

Vitamin $\mathrm{E}$ is a potent fat-soluble antioxidant that inhibits lipid peroxidation in biological membranes. In nature, compounds with vitamin $\mathrm{E}$ activity are $\alpha-, \beta-$, $\gamma-$, or $\delta$-tocopherols and $\alpha-, \beta-, \gamma-$, or $\delta$-tocotrienols. The chemical properties of these vitamin $\mathrm{E}$ isoforms include antioxidative activities. We have previously shown that dietary sesame seed or its lignan, such as sesamin and sesaminol, elevates the tocopherol concentrations in rats fed tocopherol (1-6), and the tocotrienol concentrations in rats fed the tocotrienol-rich fraction extracted from palm oil (7-9). Lemcke-Norojärvi et al. (10) recently reported that dietary sesame oil elevated the $\gamma$-tocopherol concentration in the serum of Swedish women. Thus, sesame lignan elevates the vitamin E

\footnotetext{
* Present address: Department of Nutritional Sciences, Nagoya University of Arts and Sciences, Nissin 470-0196, Japan

** Present address: Department of Food and Nutritional Environment, Kinjo Gakuin University, Nagoya 463-8521, Japan

${ }^{* * *}$ To whom correspondence should be addressed.

E-mail: kanaey@food.sugiyama-u.ac.jp

Abbreviations: CYP, cytochrome $\mathrm{P}_{450}$; DHA, docosahexaenoic acid; HPLC, high-performance liquid chromatography; MDA, malondialdehyde; TBARS, thiobarbituric acid reactive substance; $\alpha$-TTP, $\alpha$-tocopherol transfer protein.
}

concentration in humans and rats. We have also shown that the thiobarbituric acid-reactive substance (TBARS) concentrations in the tissues and plasma (or serum) of rats are decreased by dietary sesame seed or its lignan $(1,2,4-6)$. Therefore, dietary sesame seed may decrease lipid peroxidation through its effect on vitamin E activity.

Docosahexaenoic acid (DHA, 22:3 n-6), a major polyunsaturated fatty acid in fish oil, is susceptible to peroxidation because of its high degree of unsaturation. DHA or DHA-rich fish oil intake elevates the TBARS concentrations in humans $(11-14)$, rats, $(15,16)$ and mice $(17,18)$. Some reports have shown that DHA-rich fish oil intake lowers the $\alpha$-tocopherol concentration in humans (11), rats $(15,16)$, and mice $(18,19)$. These reports suggest that $\alpha$-tocopherol acts as a potent antioxidant against the lipid peroxidation induced by DHA. In this study, we determined whether or not dietary sesame lignan decreases lipid peroxidation in rats fed DHA.

\section{MATERIALS AND METHODS}

Materials. Sesamin and sesaminol were kindly provided by Takemoto Oil \& Fat (Aichi, Japan). D- $\alpha$-Tocopherol was kindly donated by Eisai (Tokyo, Japan). DHA was kindly provided by Suntory (Osaka, Japan).

Animals and diets. Male Wistar rats (3-wk-old) were purchased from Japan SLC (Shizuoka, Japan). They 
Table 1. Compositions of the experimental diets.

\begin{tabular}{|c|c|c|c|c|c|c|c|c|c|c|c|c|}
\hline & \multicolumn{6}{|c|}{ Toc 0.01} & \multicolumn{6}{|c|}{ Toc 0.05} \\
\hline & $\begin{array}{c}\text { Con- } \\
\text { trol }\end{array}$ & $\begin{array}{l}\text { Sesa- } \\
\text { min }\end{array}$ & $\begin{array}{l}\text { Sesa- } \\
\text { minol }\end{array}$ & DHA & $\begin{array}{c}\text { DHA+ } \\
\text { sesamin }\end{array}$ & $\begin{array}{c}\text { DHA+ } \\
\text { sesaminol }\end{array}$ & $\begin{array}{l}\text { Con- } \\
\text { trol }\end{array}$ & $\begin{array}{l}\text { Sesa- } \\
\text { min }\end{array}$ & $\begin{array}{l}\text { Sesa- } \\
\text { minol }\end{array}$ & DHA & $\begin{array}{c}\text { DHA+ } \\
\text { sesamin }\end{array}$ & $\begin{array}{c}\text { DHA+ } \\
\text { sesaminol }\end{array}$ \\
\hline & \multicolumn{12}{|c|}{ (g/kg diet) } \\
\hline Casein & 200 & 200 & 200 & 200 & 200 & 200 & 200 & 200 & 200 & 200 & 200 & 200 \\
\hline DL-Methionine & 3 & 3 & 3 & 3 & 3 & 3 & 3 & 3 & 3 & 3 & 3 & 3 \\
\hline Starch & 150 & 150 & 150 & 150 & 150 & 150 & 150 & 150 & 150 & 150 & 150 & 150 \\
\hline Sucrose & 500 & 498 & 498 & 495 & 493 & 493 & 500 & 498 & 498 & 495 & 493 & 493 \\
\hline Cellulose powder & 50 & 50 & 50 & 50 & 50 & 50 & 50 & 50 & 50 & 50 & 50 & 50 \\
\hline Lard & 50 & 50 & 50 & 50 & 50 & 50 & 50 & 50 & 50 & 50 & 50 & 50 \\
\hline Mineral mixture ${ }^{1}$ & 35 & 35 & 35 & 35 & 35 & 35 & 35 & 35 & 35 & 35 & 35 & 35 \\
\hline Vitamin mixture ${ }^{2}$ & 10 & 10 & 10 & 10 & 10 & 10 & 10 & 10 & 10 & 10 & 10 & 10 \\
\hline Choline bitartrate & 2 & 2 & 2 & 2 & 2 & 2 & 2 & 2 & 2 & 2 & 2 & 2 \\
\hline D- $\alpha$-Tocopherol & 0.01 & 0.01 & 0.01 & 0.01 & 0.01 & 0.01 & 0.05 & 0.05 & 0.05 & 0.05 & 0.05 & 0.05 \\
\hline DHA & & & & 5 & 5 & 5 & & & & 5 & 5 & 5 \\
\hline Sesamin & & 2 & & & 2 & & & 2 & & & 2 & \\
\hline Sesaminol & & & 2 & & & 2 & & & 2 & & & 2 \\
\hline
\end{tabular}

${ }^{1}$ AIN-76 (20), ${ }^{2}$ vitamin E-free AIN-76A (21). The rats were fed a diet with either $0.01 \mathrm{~g} / \mathrm{kg}$ (Toc 0.01) or $0.05 \mathrm{~g} / \mathrm{kg}$ (Toc $0.05)$ of $\alpha$-tocopherol. DHA, docosahexaenoic acid.

were maintained at $24.5^{\circ} \mathrm{C}$ with a 12 -h light cycle (lights on from 0800 to $2000 \mathrm{~h}$ ) and allowed free access to water and food. The rats were fed a commercial diet (CE-2, Japan Clea, Tokyo, Japan) for $7 \mathrm{~d}$ before the start of the experiment and then fed the experimental diet for $5 \mathrm{wk}$. The composition of the experimental diet is shown in Table 1 . The rats were sacrificed between 1000 and $1200 \mathrm{~h}$, and all procedures were performed in accordance with the Animal Experimentation Guidelines of Nagoya University.

The rats were fed a basal diet (control group, $n=6$ ), a diet containing $2 \mathrm{~g}$ sesamin $/ \mathrm{kg}$ (sesamin group, $n=6$ ), a diet containing $2 \mathrm{~g}$ sesaminol/ $\mathrm{kg}$ (sesaminol group, $n=6$ ), a diet containing $5 \mathrm{~g} \mathrm{DHA} / \mathrm{kg}$ (DHA group, $n=6$ ), a diet containing $2 \mathrm{~g}$ sesamin and $5 \mathrm{~g} \mathrm{DHA} / \mathrm{kg}$ (sesamin +DHA group, $n=6$ ), or a diet containing $2 \mathrm{~g}$ sesaminol and $5 \mathrm{~g} \mathrm{DHA} / \mathrm{kg}$ (sesaminol+DHA group, $n=6$ ). Each diet contained either 0.01 or $0.05 \mathrm{~g} \mathrm{D}-\alpha$ tocopherol $/ \mathrm{kg}$. The rats were fed the respective experimental diet for $5 \mathrm{wk}$. After $24 \mathrm{~h}$ of food deprivation, the rats were anesthetized with sodium pentobarbital and blood was drawn from the heart using a heparinized needle and syringe. The liver and brain were taken and stored at $-80^{\circ} \mathrm{C}$ until use for the determination of TBARS and $\alpha$-tocopherol concentrations.

Determination of TBARS concentrations. TBARS concentrations in the tissue and plasma were determined by the methods of Ohkawa et al. (22) and Yagi (23), respectively. Liver or brain $(0.5 \mathrm{~g}$ each) was homogenized in $4.5 \mathrm{~mL}$ of $11.5 \mathrm{~g} / \mathrm{L}$ potassium chloride. The tissue homogenate $(0.3 \mathrm{~mL})$ was put in a test tube, and $0.2 \mathrm{~mL}$ of $80 \mathrm{~g} / \mathrm{L} \mathrm{SDS}, 1.5 \mathrm{~mL}$ of $20 \%(\mathrm{v} / \mathrm{v})$ acetic acid and $1.5 \mathrm{~mL}$ of $8 \mathrm{~g} / \mathrm{L}$ thiobarbituric acid were added. After boiling for $1 \mathrm{~h}$, TBARS was extracted with $5 \mathrm{~mL}$ of butanol containing $62.5 \mathrm{~g} / \mathrm{L}$ pyridine and the color developed was measured with a UV-1600 spectrophotometer (Shimadzu, Kyoto, Japan) at $532 \mathrm{~nm}$. The TBARS concentration is presented as nmol malondialdehyde (MDA), using MDA as the external standard.

Determination of red blood cell hemolysis. Oxidative hemolysis of red blood cells was measured using dialuric acid (24). Heparinized blood was centrifuged at $500 \times g$ for $5 \mathrm{~min}$, and blood cells were washed with $9 \mathrm{~g} / \mathrm{L}$ sodium chloride three times. Then, the blood cells diluted with $9 \mathrm{~g} / \mathrm{L}$ sodium chloride were incubated with dialuric acid at $37^{\circ} \mathrm{C}$ for $45 \mathrm{~min}$ and centrifuged at 500 $\times g$ for $5 \mathrm{~min}$. The color of the supernatant was measured with a UV-1600 spectrophotometer (Shimadzu) at $540 \mathrm{~nm}$.

Determination of plasma pyruvate kinase activity. Plasma pyruvate kinase activity was determined by the method of Gutmann and Bernt (25) using a system coupled with lactate dehydrogenase and NADH. Plasma was added to $0.1 \mathrm{~mol} / \mathrm{L}$ triethanolamine $(\mathrm{pH} \mathrm{7.5)}$ containing $0.15 \mathrm{mmol} / \mathrm{L} \mathrm{NADH}, 1 \mathrm{mmol} / \mathrm{L}$ phosphoenolpyruvic acid, $4 \mathrm{mg} / \mathrm{L}$ lactate dehydrogenase, and $3 \mathrm{mmol} / \mathrm{L}$ ADP. The reduction of $\mathrm{NADH}$ was measured spectrophotometrically at $340 \mathrm{~nm}$ for $5 \mathrm{~min}$ at $37^{\circ} \mathrm{C}$ using the molar absorption coefficient for NADH. A unit of pyruvate kinase activity was equivalent to the activity needed to catalyze the reaction of $1 \mu \mathrm{mol}$ of ADP to ATP for $1 \mathrm{~min}$.

Determination of $\alpha$-tocopherol concentration. Liver or brain $(0.5 \mathrm{~g}$ each) was homogenized in $4.5 \mathrm{~mL}$ of distilled water. The liver or brain homogenate $(0.5 \mathrm{~mL})$ was put in a test tube, and $0.5 \mathrm{~mL}$ of ethanol containing $60 \mathrm{~g} / \mathrm{L}$ pyrogallol and $0.45 \mu \mathrm{g}$ of $2,2,5,7,8$-pentamethyl-6-chroman as the internal standard were added. 
A

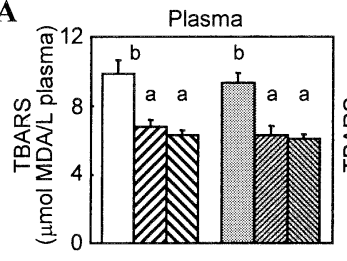

B

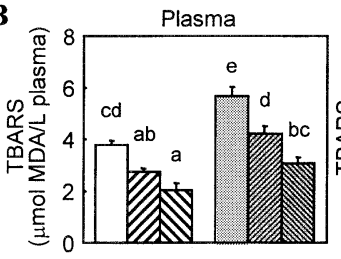

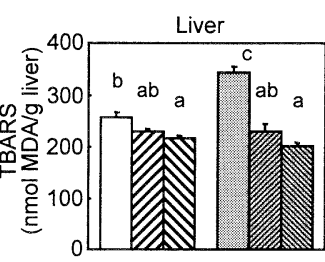

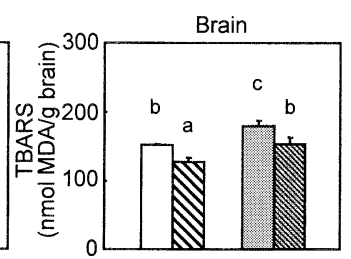

$\square$ Control

Sesamin

D Sesaminol

DHA

DHA+sesamin

DHA+sesaminol

Liver

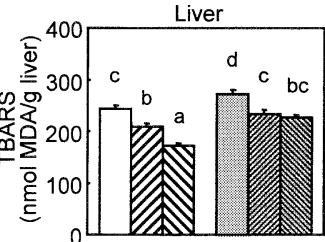

Fig. 1. Effects of dietary sesamin and sesaminol on thiobarbituric acid reactive substance (TBARS) concentrations in the plasma, liver, and brain of rats fed diets with or without docosahexaenoic acid (DHA). The rats were fed a basal diet (Control), a diet with sesamin (Sesamin), a diet with sesaminol (Sesaminol), a diet containing DHA (DHA), a diet containing DHA with sesamin (DHA+sesamin), or a diet containing DHA with sesaminol (DHA + sesaminol), for 5 wk. Each diet contained either $0.01 \mathrm{~g} / \mathrm{kg}$ (A) or $0.05 \mathrm{~g} / \mathrm{kg}$ (B) of $\alpha$-tocopherol. Values are means $+\mathrm{SE}, n=6$. Means not sharing a letter are different, $p<0.05$. MDA, malondialdehyde.

Then, $0.1 \mathrm{~mL}$ of $600 \mathrm{~g} / \mathrm{L}$ potassium hydroxide was added and saponified at $70^{\circ} \mathrm{C}$ for $30 \mathrm{~min}$. After the addition of $2.25 \mathrm{~mL}$ of $20 \mathrm{~g} / \mathrm{L}$ sodium chloride, tocopherol was extracted with $0.5 \mathrm{~mL}$ of hexane containing $10 \%$ $(\mathrm{v} / \mathrm{v})$ ethylacetate. Plasma $(75 \mu \mathrm{L})$ was put in a test tube, and 90 ng of 2,2,5,7,8-pentamethyl-6-chroman as the internal standard was added. After the addition of $0.5 \mathrm{~mL}$ of distilled water and $1.0 \mathrm{~mL}$ of ethanol, tocopherol was extracted with $5 \mathrm{~mL}$ of hexane.

The $\alpha$-tocopherol concentration was determined by HPLC (26). Instrumentation used for HPLC was a LC10AS (Shimadzu) with a RF-10AXL fluorescence detector (Shimadzu) at excitation $298 \mathrm{~nm}$ and emission $325 \mathrm{~nm}$. The analytical column used was a Develosil $\mathrm{NH}_{2}-5 \quad(4.6 \times 150 \mathrm{~mm}$, Nomura Chemical, Aichi, Japan). The mobile phase was hexane containing $1 \%$ (v/v) isopropylalcohol, and the flow rate was $1 \mathrm{~mL} / \mathrm{min}$.

Determination of docosahexaenoic acid content. Total lipids were extracted from the plasma and liver by the method of Bligh and Dyer (27). Triacylglycerol and phospholipids were separated by Sep-Pak Plus Silica Cartridges (Nihon Waters, Tokyo, Japan) and methylated in $3 \mathrm{~mol} / \mathrm{L}$ methanolic hydrochloric acid at $50^{\circ} \mathrm{C}$ for $3 \mathrm{~h}$. The fatty acid methyl esters were extracted with hexane and measured by gas-liquid chromatography using a GC-12APF with a flame ionization detector (Shimadzu). The analytical glass column was an Advance-DS 5\% Chromosorb W80/100 glass column $(3.2 \mathrm{~mm} \times 2.1 \mathrm{~m}$, Shinwa Chemical Industries, Kyoto, Japan). The column and injector temperatures were $190^{\circ} \mathrm{C}$ and $240^{\circ} \mathrm{C}$, respectively.

Statistical analysis. Data are presented as means \pm SE, $n=6$. They were analyzed by one-way ANOVA with Fisher's post-hoc test. Differences with a $p$-value $<0.05$ were regarded as significant.

\section{RESULTS}

Dietary DHA or sesame lignan did not affect the food intake or growth of rats during the experimental period

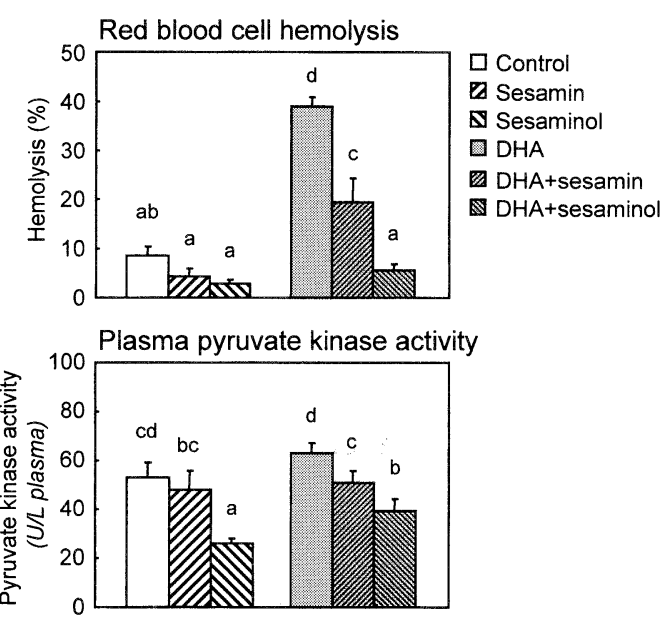

Fig. 2. Effects of dietary sesamin and sesaminol on red blood-cell hemolysis and plasma pyruvate kinase activity of rats fed diets with or without docosahexaenoic acid (DHA). The rats were fed a basal diet (Control), a diet with sesamin (Sesamin), a diet with sesaminol (Sesaminol), a diet containing DHA (DHA), a diet containing DHA with sesamin (DHA+sesamin), or a diet containing DHA with sesaminol (DHA+sesaminol), for $5 \mathrm{wk}$. The diet contained $0.01 \mathrm{~g} \alpha$-tocopherol $/ \mathrm{kg}$. The hemolysis was determined using dialuric acid. Values are means $+\mathrm{SE}, n=6$. Means not sharing a letter are different, $p<0.05$. U, a unit which catalyzes the reaction of $1 \mu \mathrm{mol}$ of ADP to ATP for $1 \mathrm{~min}$.

(data not shown).

In the rats fed a diet with $0.01 \mathrm{~g} \alpha$-tocopherol $/ \mathrm{kg}$ (Fig. 1A), the TBARS concentration in the liver and brain of the DHA group was higher $(p<0.05)$ than that of the control group. The dietary sesamin and sesaminol lowered $(p<0.05)$ the TBARS concentration in the plasma, liver, and brain of the rats fed diets with or without DHA. In the rats fed a diet with $0.05 \mathrm{~g} \alpha$-tocopherol/kg (Fig. 1B), the TBARS concentration in the plasma and liver of the DHA group was higher $(p<0.05)$ than that of the control group. The dietary 
A


Brain
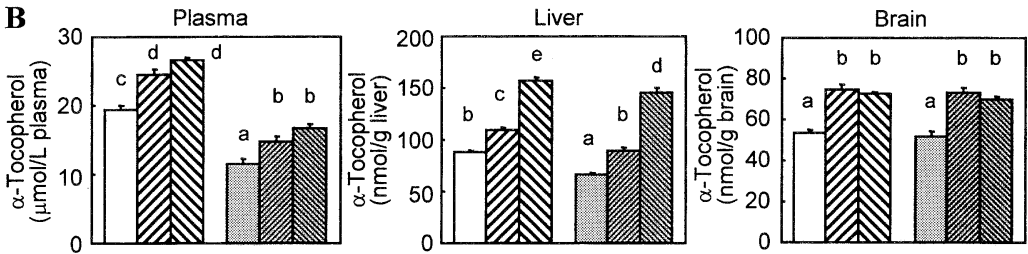

Fig. 3. Effects of dietary sesamin and sesaminol on $\alpha$-tocopherol concentrations in the plasma, liver, and brain of rats fed diets with or without docosahexaenoic acid (DHA). The rats were fed a basal diet (Control), a diet with sesamin (Sesamin), a diet with sesaminol (Sesaminol), a diet containing DHA (DHA), a diet containing DHA with sesamin (DHA+ sesamin), or a diet containing DHA with sesaminol (DHA+sesaminol), for $5 \mathrm{wk}$. Each diet contained either $0.01 \mathrm{~g} / \mathrm{kg}(\mathrm{A}) \mathrm{or} 0.05 \mathrm{~g} / \mathrm{kg}$ (B) of $\alpha$-tocopherol. Values are means + SE, $n=6$. Means not sharing a letter are different, $p<0.05$.

sesamin or sesaminol lowered $(p<0.05)$ the TBARS concentration in the plasma, liver, and brain of the rats fed diets with or without DHA.

The red blood-cell hemolysis induced by dialuric acid in the rats fed the diet with $0.01 \mathrm{~g} \alpha$-tocopherol $/ \mathrm{kg}$ was measured (Fig. 2). The red blood-cell hemolysis of the DHA group was much greater $(p<0.05)$ than that of the control group. The hemolysis of the DHA + sesamin and DHA+sesaminol groups were much lower $(p<0.05)$ than that of the DHA group. The hemolysis of the DHA + sesaminol group was not different ( $p \geq 0.05$ ) from those of the control, sesamin and sesaminol groups fed diets without DHA. The pyruvate kinase activity in the plasma of the rats fed the diet with $0.01 \mathrm{~g}$ $\alpha$-tocopherol $/ \mathrm{kg}$ was also measured (Fig. 2). The pyruvate kinase activity of the $\mathrm{DHA}+$ sesamin group was lower $(p<0.05)$ than that of the DHA group. The dietary sesaminol lowered $(p<0.05)$ the pyruvate kinase activity in the plasma of the rats fed diets with or without DHA.

The $\alpha$-tocopherol concentrations in the plasma, liver, and brain are shown in Fig. 3. In the rats fed the diet with $0.01 \mathrm{~g} \alpha$-tocopherol/kg (Fig. 3A), the $\alpha$-tocopherol concentration in the plasma and liver of the DHA group was lower $(p<0.05)$ than that of the control group. The dietary sesamin or sesaminol elevated $(p<0.05)$ the $\alpha$ tocopherol concentrations in the plasma, liver, and brain. The $\alpha$-tocopherol concentrations in the plasma and liver of the DHA+sesamin and DHA+sesaminol groups were not different $(p \geq 0.05)$ from that of each control group. The dietary DHA also lowered $(p<0.05)$ the $\alpha$-tocopherol concentrations in the plasma and liver of the rats fed the diet with $0.05 \mathrm{~g} \alpha$-tocopherol $/ \mathrm{kg}$, although it did not affect $(p \geq 0.05)$ the $\alpha$-tocopherol concentration in the brain (Fig. 3B). The dietary sesamin and sesaminol elevated $(p<0.05)$ the $\alpha$-tocopherol concentration in the plasma, liver, and brain of the rats fed diets with or without DHA.

The dietary sesamin did not affect the triacylglycerol concentrations in the plasma and liver in this study
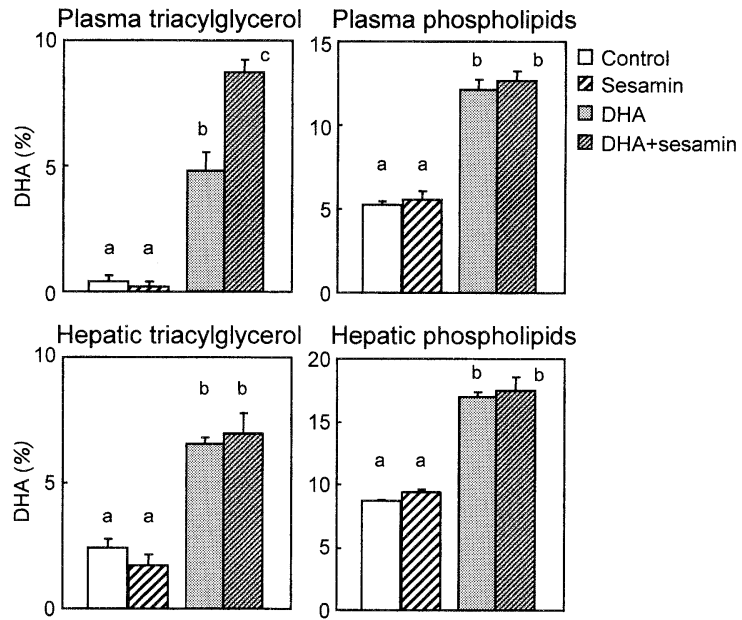

Fig. 4. Effect of dietary sesamin on the percentage of docosahexaenoic acid (DHA) in the fatty acid composition of the plasma and liver of rats fed diets with or without DHA. The rats were fed a basal diet (Control), a diet with sesamin (Sesamin), a diet containing DHA (DHA), or a diet containing DHA with sesamin (DHA + sesamin), for $5 \mathrm{wk}$. The diet contained $0.01 \mathrm{~g} \alpha$ tocopherol $/ \mathrm{kg}$. Values are means $+\mathrm{SE}, n=6$. Means not sharing a letter are different, $p<0.05$.

(data not shown). The dietary DHA elevated the percentage of DHA in the fatty acid composition of both triacylglycerol and phospholipids in the plasma and liver of the rats fed the diet with $0.01 \mathrm{~g} \alpha$-tocopherol $/ \mathrm{kg}$ (Fig. $4)$. The DHA percentage of the plasma triacylglycerol of the DHA+sesamin group was higher $(p<0.05)$ than that of the DHA group, although the effect of sesamin was not detected $(p \geq 0.05)$ in the plasma phospholipids. However, the dietary sesamin did not affect the DHA percentage of the triacylglycerol or phospholipids in the liver.

\section{DISCUSSION}

Several reports have shown that DHA or DHA-rich fish oil intake elevates the TBARS concentrations in 
humans (11-14), rats $(15,16)$, and mice $(17,18)$. In this study, dietary DHA elevated the TBARS concentrations in the liver and brain of rats fed a diet with $0.01 \mathrm{~g}$ $\alpha$-tocopherol/kg (Fig. 1A) and the plasma and liver of rats fed a diet with $0.05 \mathrm{~g} \alpha$-tocopherol $/ \mathrm{kg}$ (Fig. 1B). Dietary DHA also increased the red blood-cell hemolysis induced by dialuric acid, and tended to elevate the plasma pyruvate kinase activity in rats fed the diet with $0.01 \mathrm{~g} \alpha$-tocopherol/kg (Fig. 2). Thus, dietary DHA induces lipid peroxidation and weakness of the biological membranes because of its high degree of unsaturation. We have previously shown that dietary sesamin and sesaminol decrease the TBARS concentrations in the liver of rats fed a diet containing $0.01 \mathrm{~g} \alpha$-tocopherol/kg and sesamin or sesaminol (2). The dietary lignans also prevented red blood-cell hemolysis and lowered the plasma pyruvate kinase activity (2). In this study, the dietary sesame lignans significantly lowered the TBARS concentrations in the plasma, liver, and brain of the rats fed diets with or without DHA (Fig. 1). It also prevented red blood-cell hemolysis and lowered the plasma pyruvate kinase activity in the rats fed DHA (Fig. 2). Thus, sesame lignans decrease lipid peroxidation and improve the weakness of biological membranes in rats fed diets with DHA.

DHA-rich fish oil intake lowers the $\alpha$-tocopherol concentration in humans $(11)$, rats $(15,16)$, and mice $(18$, 19). These data suggest that $\alpha$-tocopherol acts as an antioxidant for the inhibition of lipid peroxidation in DHA-rich biological membranes. The dietary sesame lignans elevated the $\alpha$-tocopherol concentrations in the plasma, liver, and brain of the rats fed diets with or without DHA (Fig. 3). Moreover, dietary sesame seed elevated the $\alpha$-tocopherol concentration in the red blood cell of rats fed diets with 0.01 or $0.05 \mathrm{~g} \alpha$-toco$\mathrm{pherol} / \mathrm{kg}(2)$. These results suggest that dietary sesame lignans inhibit the lipid peroxidation induced by DHA intake by elevating the $\alpha$-tocopherol concentration. Dietary sesamin also elevated the DHA content in the plasma triacylglycerol (Fig. 4). This result suggests the possibility that elevation of the $\alpha$-tocopherol concentration utilizing dietary sesamin prevents the degradation of DHA in plasma triacylglycerol.

On the other hand, we have studied the effect of dietary sesame seed or its lignans on the vitamin E metabolism in rats. Dietary $\alpha$-tocopherol is absorbed in the intestine and carried to the liver as a result of the uptake of chylomicron remnants (28). Sesame lignan does not affect the absorption of $\alpha$-tocopherol nor chylomicron secretion by the intestine (9). $\alpha$-Tocopherol transfer protein ( $\alpha$-TTP), tocopherol-associated protein, and tocopherol-binding protein have been reported as the tocopherol-regulatory proteins that determine the tissue tocopherol levels (29). It is thought that $\alpha$-TTP plays an important role in the discrimination of vitamin E isoforms (30). $\alpha$-TTP catalyzes $\alpha$-tocopherol secretion by a novel non-Golgi-mediated pathway in liver cells, and $\alpha$-tocopherol is incorporated into very-low-density lipoprotein and subsequently transported to the various tissues by lipoproteins (31). Some reports show that the
$\alpha$-TTP concentration in the liver of rats changed during $\alpha$-tocopherol deficiency (32) and in the developmental period after birth (33). However, the dietary sesame seed did not affect the $\alpha$-TTP concentration in the liver of rats fed $\alpha$-tocopherol with sesame seed (data not shown). The excess amount of $\alpha$-tocopherol is metabolized to carboxychroman (34) and excreted into urine. It has recently been suggested that the $\omega$-oxidation of tocopherol, the initiating and rate-limiting step of tocopherol degradation to carboxychroman, is catalyzed by some cytochrome $\mathrm{P}_{450}$ (CYP) isoforms (5, 35-37). Sesamin inhibits the CYP-dependent oxidation of $\gamma$-tocopherol in HepG2 (35) and microsomes expressing recombinant human CYP4F (37), and the dietary sesamin and sesaminol decrease the urinary excretion of carboxychroman in rats fed $\gamma$-tocopherol (5). These data suggest that dietary sesame lignans elevate the tocopherol concentration by inhibiting the vitamin $\mathrm{E}$ metabolism. Therefore, the sesame lignans may inhibit the $\alpha$-tocopherol metabolism to carboxychroman in rats fed DHA.

Both sesamin and sesaminol elevated the $\alpha$-tocopherol concentration in the plasma, liver, and brain of rats (Fig. 3). The $\alpha$-tocopherol concentration in the liver of the rats fed the diets with sesaminol for $5 \mathrm{wk}$ was higher than that of the rats fed the diets with sesamin. We previously showed a high $\alpha$-tocopherol concentration in the plasma and liver of rats fed a diet with sesaminol for $8 \mathrm{wk}$ (2). However, the $\gamma$-tocopherol concentrations in the liver, kidney, brain, and serum, and the urinary excretion of carboxychroman of the rats fed diets containing $\alpha$-tocopherol with sesamin or sesaminol for a short period ( $3 \mathrm{~d}$ ) did not differ (5). These data suggest that the inhibitory effects of sesamin and sesaminol on the tocopherol metabolism were almost the same. The reason why the $\alpha$-tocopherol concentration in the liver of the rats fed diets with sesaminol for a long period ( 5 or $8 \mathrm{wk}$ ) was higher than that of the rats fed diets with sesamin is unknown. In contrast to sesamin, sesaminol has a hydroxyl group (1) and shows antioxidative activity. We previously suggested that sesaminol was a potent antioxidant against lipid peroxidation in vivo (9). Sesaminol may act as an antioxidant against the oxidative degradation of $\alpha$-tocopherol and lipid peroxidation in biological membranes. Moreover, Nakai et al. (38) recently identified some metabolites of sesamin in rat bile after the oral administration of sesamin, and suggested that the metabolites had radical-scavenging activity and decreased lipid peroxidation in vitro. Therefore, sesame lignans may decrease lipid peroxidation not only elevating the $\alpha$-tocopherol concentration, but also by their antioxidative activity or that of their metabolites directly.

\section{Acknowledgments}

The authors thank K. Akimoto (Intellectual Property Department, Suntory Ltd., Tokyo, Japan) for his valuable advice on the determination of the fatty acid compositions in the plasma and liver samples. 


\section{REFERENCES}

1) Yamashita K, Nohara Y, Katayama K, Namiki M. 1992. Sesame seed lignans and $\gamma$-tocopherol act synergistically to produce vitamin $\mathrm{E}$ activity in rats. J Nutr $\mathbf{1 2 2}$ : 2440-2446.

2) Yamashita K, Iizuka Y, Imai T, Namiki M. 1995. Sesame seed and its lignans produce marked enhancement of vitamin $\mathrm{E}$ activity in rats fed a low $\alpha$-tocopherol diet. Lipids 30: 1019-1028.

3) Yamashita K, Takeda N, Ikeda S. 2000. Effects of various tocopherol-containing diets on tocopherol secretion into bile. Lipids 35: 163-170.

4) Ikeda S, Yasumoto-Shirato S, Yamashita K. 2000. Increased vitamin $\mathrm{E}$ concentration in rats fed with sesame seeds containing a high level of lignans. Nihon Kasei Gakkaishi (J Home Econ Jpn) 51: 1017-1025 (in Japanese).

5) Ikeda S, Tohyama T, Yamashita K. 2002. Dietary sesame seed and its lignans inhibit 2,7,8-trimethyl-2(2'-carboxyethyl)-6-hydroxychroman excretion into urine of rats fed $\gamma$-tocopherol. J Nutr 132: 961-966.

6) Ikeda S, Ohta T, Yasumoto-Shirato S, Yamashita K. 2002. Increased tocopherol concentration by dietary sesame seeds: comparison between rats and mice. Nihon Kasei Gakkaishi (J Home Econ Jpn) 53: 309-315 (in Japanese).

7) Iizuka Y, Namiki M, Yamashita K. 1997. Effect of sesame seed lignans on vitamin $\mathrm{E}$ activity in rats fed on a tocopherol and tocotrienol mixture containing $\alpha$-tocopherol. Nihon Kasei Gakkaishi (J Home Econ Jpn) 48: 575-581 (in Japanese).

8) Ikeda S, Toyoshima K, Yamashita K. 2001. Dietary sesame seeds elevate $\alpha$ - and $\gamma$-tocotrienol concentrations in skin and adipose tissue of rats fed the tocotrienol-rich fraction extracted from palm oil. J Nutr 131: 28922897.

9) Yamashita K, Ikeda S, Iizuka Y, Ikeda I. 2002. Effect of sesaminol on plasma and tissue $\alpha$-tocopherol and $\alpha$ tocotrienol concentrations in rats fed a vitamin E concentrate rich in tocotrienols. Lipids 37: 351-358.

10) Lemcke-Norojärvi M, Kamal-Eldin A, Appelqvist L- $\AA$, Dimberg LH, Öhrvall M, Vessby B. 2001. Corn and sesame oils increase serum $\gamma$-tocopherol concentrations in healthy Swedish women. J Nutr 131: 1195-1201.

11) Palozza P, Sgarlata E, Luberto C, Piccioni E, Anti M, Marra G, Armelao F, Franceschelli P, Bartoli GM. 1996. n-3 Fatty acids induce oxidative modifications in human erythrocytes depending on dose and duration of dietary supplementation. Am J Clin Nutr 64: 297-304.

12) Hansen JB, Berge RK, Nordøy A, Bønaa KH. 1998. Lipid peroxidation of isolated chylomicrons and oxidative status in plasma after intake of highly purified eicosapentaenoic or docosahexaenoic acids. Lipids 33: 11231129.

13) Higdon JV, Liu J, Du SH, Morrow JD, Ames BN, Wander RC. 2000. Supplementation of postmenopausal women with fish oil rich in eicosapentaenoic acid and docosahexaenoic acid is not associated with greater in vivo lipid peroxidation compared with oils rich in oleate and linolrate as assessed by plasma malondialdehyde and $\mathrm{F}_{2-}$ isoprostanes. Am J Clin Nutr 72: 714-722.

14) Wander RC, Du SH. 2000. Oxidation of plasma proteins is not increased after supplementation with eicosapentaenoic and docosahexaenoic acids. Am J Clin Nutr $\mathbf{7 2}$ :
731-737.

15) Mouri K, Ikesu H, Esaka T, Igarashi O. 1984. The influence of marine oil intake upon levels of lipids, $\alpha$-tocopherol and lipid peroxidation in serum and liver of rats. J Nutr Sci Vitaminol 30: 307-318.

16) Song JH, Miyazawa T. 2001. Enhanced level of n-3 fatty acid in membrane phospholipids induces lipid peroxidation in rats fed dietary docosahexaenoic acid. Atherosclerosis 155: 9-18.

17) Gonzalez MJ, Gray JI, Schemmel RA, Dugan Jr L, Welsch CW. 1992. Lipid peroxidation products are elevated in fish oil diets even in the presence of added antioxidants. J Nutr 122: 2190-2195.

18) Yasuda S, Watanabe S, Kobayashi T, Okuyama H. 1998. Effects of dietary unsaturated fatty acid and chronic carbon tetrachloride treatment on the accumulation of oxidation products, $\alpha$-tocopherol and liver injury in mice. Biol Pharm Bull 21: 1050-1056.

19) Yasuda S, Watanabe S, Kobayashi T, Okuyama H. 1997. Docosahexaenoic acid-rich fish oil does not enhance the elevation of serum transaminase and liver triacylglycerol induced by carbon tetrachloride in mice. Lipids $\mathbf{3 2}$ : 1249-1255.

20) American Institute of Nutrition. 1977. Report of the American Institute of Nutrition ad hoc committee on standards for nutritional studies. J Nutr 107: 13401348.

21) American Institute of Nutrition. 1980. Second report of the ad hoc committee on standards for nutritional studies. J Nutr 110: 1726.

22) Ohkawa H, Ohishi N, Yagi K. 1979. Assay for lipid peroxides in animal tissues by thiobarbituric acid reaction. Anal Biochem 95: 351-358.

23) Yagi K. 1976. A simple fluorometric assay for lipoperoxide in blood plasma. Biochem Med 15: 212-216.

24) Mino M, Kitagawa M, Nakagawa S. 1981. Changes of $\alpha$ tocopherol levels in red blood cells and plasma with respect to hemolysis induced dialuric acid in vitamin $\mathrm{E}$ deficient rats. J Nutr Sci Vitaminol 27: 199-207.

25) Gutmann I, Bernt E. 1974. Pyruvate kinase assay in serum and erythrocytes. In: Methods of Enzymatic Analysis (Bergmeyer HU, ed), vol 2, p 774-778. Academic Press, New York.

26) Ueda T, Igarashi O. 1987. New solvent system for extraction of tocopherols from biological specimens for HPLC determination and the evaluation of 2,2,5,7,8pentamethyl-6-chromanol as an internal standard. J Micronutr Anal 3: 185-198.

27) Bligh EG, Dyer WJ. 1959. A rapid method of total lipid extraction and purification. Can J Biochem Physiol 37: 911-917.

28) Traber MG, Sie H. 1996. Vitamin E in humans: demand and delivery. Annu Rev Nutr 16: 321-347.

29) Blatt DH, Leonard SW, Traber MG. 2001. Vitamin E kinetics and the function of tocopherol regulatory proteins. Nutrition 17: 799-805.

30) Hosomi A, Arita M, Sato $Y$, Kiyose C, Ueda T, Igarashi $O$, Arai H, Inoue K. 1997. Affinity for $\alpha$-tocopherol transfer protein as a determinant of the biological activities of vitamin E analogs. FEBS Lett 409: 105-108.

31) Traber MG, Arai H. 1999. Molecular mechanisms of vitamin E transport. Annu Rev Nutr 19: 343-355.

32) Shaw H-M, Huang C-J. 1998. Liver $\alpha$-tocopherol transfer protein and its mRNA are differentially altered by dietary vitamin $\mathrm{E}$ deficiency and protein insufficiency in 
rats. J Nutr 128: 2348-2354.

33) Tamai H, Kim H-S, Arai H, Inoue K, Mino M. 1998. Developmental changes in the expression of $\alpha$-tocopherol transfer protein during the neonatal period of rat. Biofactors 7: 87-91.

34) Schultz M, Leist M, Petrzika M, Gassmann B, BrigeliusFlohé R. 1995. Novel urinary metabolite of $\alpha$-tocopherol, 2,5,7,8-tetramethyl-2(2'-carboxyethyl)-6-hydroxychroman, as an indicator of an adequate vitamin $\mathrm{E}$ supply? Am J Clin Nutr 62: 1527S-1534S.

35) Parker RS, Sontag TJ, Swanson JE. 2000. Cytochrome P4503A-dependent metabolism of tocopherols and inhibition by sesamin. Biochem Biophys Res Commun
277: 531-534.

36) Birringer M, Drogan D, Brigelius-Flohé R. 2001. Tocopherols are metabolized in HepG2 cells by side chain $\omega$ oxidation and consecutive $\beta$-oxidation. Free Radic Biol Med 31: 226-232.

37) Sontag TJ, Parker RS. 2002. Cytochrome P450 $\omega$ hydroxylase pathway of tocopherol catabolism. Novel mechanism of regulation of vitamin E status. J Biol Chem 277: 25290-25296.

38) Nakai M, Harada M, Nakahara K, Akimoto K, Shibata H, Miki W, Kiso Y. 2003. Novel antioxidative metabolites in rat liver with ingested sesamin. J Agric Food Chem 51: 1666-1670. 